\title{
THE IMPACT OF EARTHQUAKE ON CHILD TEST SCORE
}

\author{
Eny Sulistyaningrum \\ Faculty of Economics and Business, Universitas Gadjah Mada, Indonesia \\ (eny@ugm.ac.id)
}

\begin{abstract}
Natural disasters always affect different aspects of individual life. They affect almost every part of life, such as the emotional, economic, physical, social, and environmental aspects. Children are believed to be very vulnerable to disasters. The increasing frequency of disasters and the intensity of their destruction motivate an analysis of the impacts of disasters, especially on education, for children. This paper uses a micro level survey data set from the Indonesian Family Life Survey (IFLS) which covers approximately $83 \%$ of the Indonesian population within the survey area. The main objective of this paper is to examine the effects of earthquakes on students' performance, measured by their child test scores. This type of disaster was chosen because of its intensity, as measured by the percentage of people killed, and the percentage of people evacuated. Moreover, we also investigate the children who took the test immediately after the earthquake and compare their scores with those whose tests were a year after the earthquake. Arguably an earthquake is an exogenous event, so we use the exogenous variation of earthquake as a natural experiment design to estimate the effect of earthquakes on child test scores. A Difference in Difference model (DiD) can be used for estimating if a certain group is exposed to the causal variable of interest, such as an earthquake, and other groups are not. The results confirm that child test scores are significantly affected by earthquakes.
\end{abstract}

Keywords: earthquake, child test score, DiD model

JEL Codes: I00, I25, I29, O15

\section{INTRODUCTION}

Seriously or not, a natural disaster always affects different aspects of individual life. The effect includes the emotional, economic, physical, social, and environmental parts of life. Among the most vulnerable from a disaster are children. Given the increasing frequency and the intensity of destruction caused by disasters, it is important to analyse the impacts of disasters, especially on the education of children. This paper uses a micro level survey data set from the Indonesian Family Life Survey (IFLS) which covers approximately $83 \%$ of the Indonesian population within the survey area. The main objective of this paper is to examine the effects of earthquakes on students' performance, as measured by their child test scores. Earthquakes were chosen because of their intensity, as measured by the percentage of people killed, and the percentage of people evacuated. Moreover, this study also investigates the children who took the test immediately after the earthquake and compares their results with the results of those whose tests were a year after the earthquake.

This paper contributes to the international literature in several respects. First, compared to the other literature, this study uses self-reported data, on whether households are affected by earthquakes or not. In our data, individuals are categorised as affected by an earthquake if they reported that their household experienced a death or major injuries to the household's members, direct financial loss to the household, or the relocation of the household's members. That definition seems more accurate, rather than only using the general information of before and after the shock and there has been no sense of which individual is affected or unaffected. Second, this study investigates the impact of earthquakes on child test scores. Previous studies investigated the impact of disasters on a quantity measure of educational outcome - such as school enrolment or attendance - rather than the quality of any outcome. Third, this study examines the impact of earthquakes across the distribution of 
test scores using a Quantile Regression (QR), so it can see in detail the effects of earthquakes by the groups of outcomes.

An innovation of this research that differs from the previous literature is to separate the effects of an earthquake into two parts. The first effect is calculated for individuals in the earthquake region, both those who report that they are affected and those who say they are unaffected but live in the area of the earthquake. The second effect is an additional effect for those who report that they have been directly affected by the earthquake. In addition, it also estimates the impact on children who took the test immediately after the earthquake and compares this with those who took the tests a year after the earthquake. Our major finding shows that earthquakes affect all of the children in an earthquake region, both those who declare they are affected and those who say they are unaffected by earthquakes. Those who are affected by disasters had a lower test score than those who were unaffected but also lived in the disaster region. Moreover, children who took the test just after a disaster had lower test scores than children who took the test more than a year after a disaster. There are also different impacts from different types of earthquakes and we find that only large earthquakes are associated with lower test scores for all children in a disaster region. Living in a region that is hit by an earthquake has the biggest impact on child test scores in the lowest quantile of the conditional test scores. The largest additional impact of earthquakes, for those who have been affected by disasters, is on children at the median of the test score's distribution.

This study uses the Indonesian Family Life Survey IFLS4 (2007) and some from IFLS3 (2000). IFLS provides all educational and disaster information at individual, household and community levels. Besides, there are two other data sets used: the official disaster data base from the National Disaster Management Agency (BNPB = Badan Nasional Penanggulangan Bencana) of Indonesia and statistics of Indonesian data from the Central Bureau of Statistics of Indonesia (BPS = Badan Pusat Statistik).

\section{INDONESIA'S DISASTERS}

The data are from the last decade of disasters, around the years 2000-2011. More than 4,000 disasters occurred and were recorded by the National Disaster Management Agency (BNPB) across various regions. Some of them were very destructive and killed many people in some regions in Indonesia. The most destructive one was the earthquake and tsunami in Aceh on 26th December 2004 it had a 9.1 - 9.3 moment magnitude scale, and stated as the longest duration in history since it lasted for 10 minutes. In fact, the disaster killed approximately 230,000 people in fourteen countries, and more than half of the people, approximately around 126,915 people, were from Indonesia. In addition, according to BNBP, 37,063 people were missing and 655,000 people were made homeless across Aceh province. The second destructive disaster was an earthquake on $26^{\text {th }}$ May 2006 occurred in Yogyakarta province. As a result, more than 6,000 people were killed in a 6.3 magnitude earthquake and about 130,000 were left homeless. Another serious disaster was the floods in Jakarta in February 2007. Around 30 people were killed and approximately 340,000 left homeless. Another earthquake in West Sumatra that measured 5.8-6.4 on the Richter scale killed approximately 50 people on 6 March 2007.

Figure 1 shows the distribution of the percentage of the number of dead and evacuated people to the population across the regions. The dark colour is for the percentage of evacuated people to the population, while the light colour is for the percentage of dead people to the population. After excluding the Aceh region, Yogyakarta had the highest percentage of both ratios. West Sumatra and West Papua were in second and third places, in terms of the percentage of deaths and evacuated people. In terms of the percentage of evacuated people, some regions with high percentages were DKI Jakarta, South Kalimantan, Gorontalo and North Sumatra. This information is used in the empirical analysis to define disaster regions for further analysis.

In order to capture the intensity of disasters, Figure 2 demonstrates the number of deaths for 
each disaster by year. After excluding the tsunami and earthquake in Aceh in 2004, due to a huge number of victims, the earthquake in Yogyakarta in 2006 resulted in the highest number of deaths.

Based on the disaster data information presented in Figure 2, the earthquake in Yogyakarta in 2006 was the most destructive in the last decade. Thus, this paper defines the dummies ER (Earthquake Region) and A (being affected by earthquake). ER is equal to 1 if individuals are in the earthquake region (Yogyakarta) at the time of the earthquake and A is equal to 1 if individuals are in the earthquake region and were affected by the earthquake. As explained above, in instances where the individuals suffered financial loss or where one or more household member died or suffered major injuries, this is defined as being affected by the earthquake.

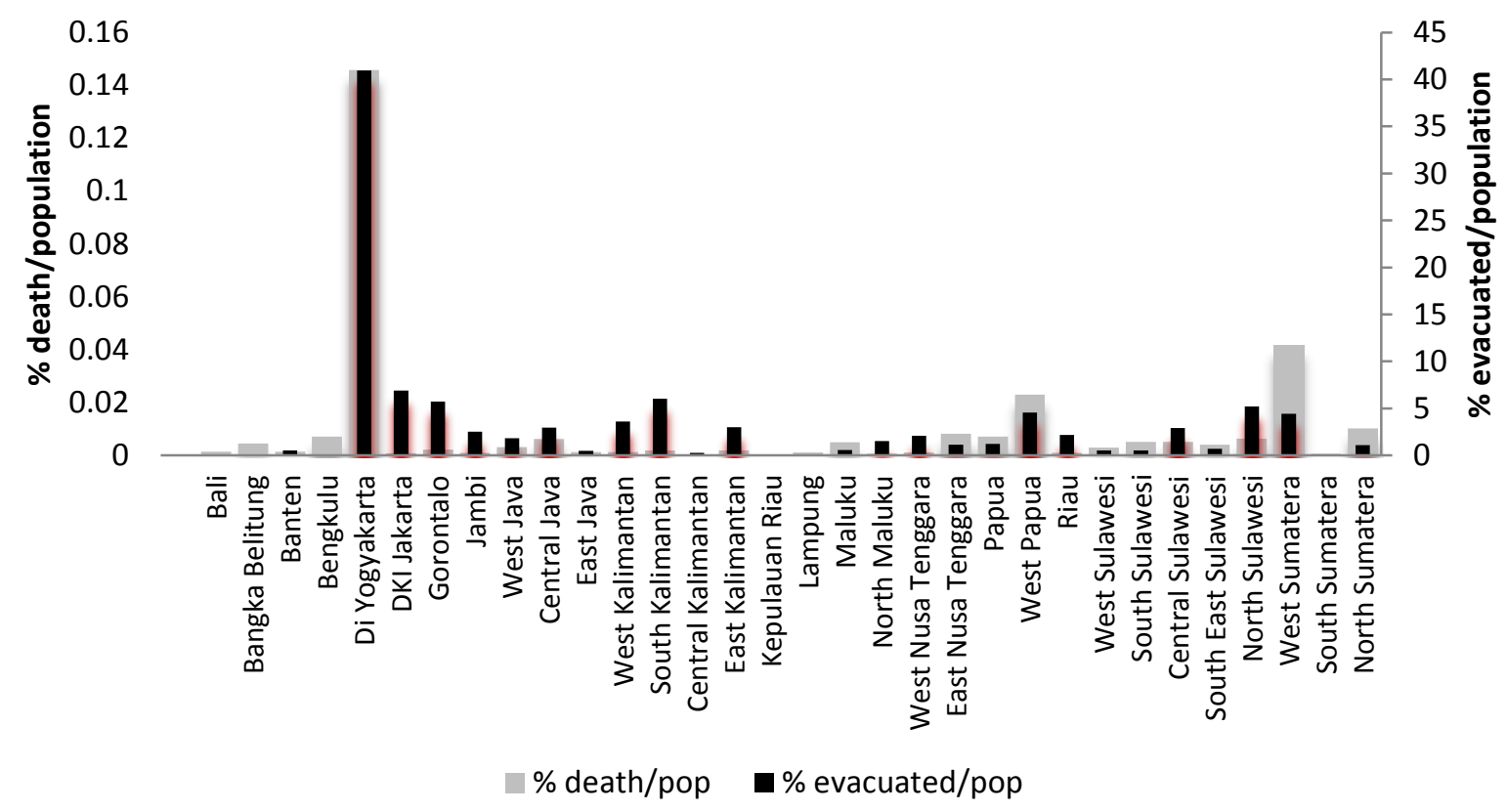

Figure 1. Percentage of total number of dead and evacuated people to the population during disaster by province

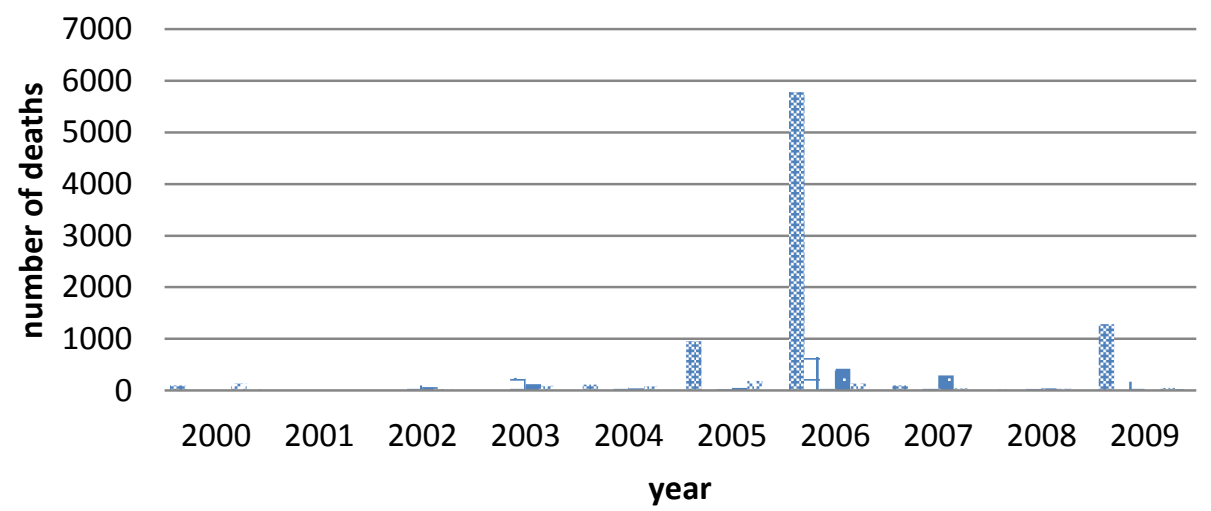

EARTHQUAKE

I EARTHQUAKE AND TSUNAMI + FLOODS

. FLOODS AND LANDSLIDES

LANDSLIDES

$\sim$ STRONG WIND

Source: National Disaster Management Agency

Figure 2. The number of deaths in each type of disaster by year 



\section{EDUCATIONAL DATA}

The important data on education is the child test score. A child test score is obtained from the test score in primary school, either at age 11 or in their final year of primary school. All the questions in the test are standard for all the regions in Indonesia and the test is conducted nationally, at the same time. The test score has a continuous value and ranges from 0 to 10 . It is calculated from the average scores of 3 subjects (maths, science and the Indonesian language). Test score data from the IFLS survey are only taken from the respondents who could show test certificates and excludes the respondents who could not show their certificates, since sometimes the information was not complete. For instance, they only mentioned 2 subjects out of 3, or they only mentioned the total score without mentioning each of the subjects, because they did not remember their scores in detail. Figure 3 presents the comparison distribution between child test scores in the earthquake and non-earthquake regions in the time before and after a disaster. It seems that child test scores in the earthquake region were badly affected, while child test scores in the non-earthquake region are not badly affected if compared to the scores before and after a disaster.

a. Earthquake region (Yogyakarta)

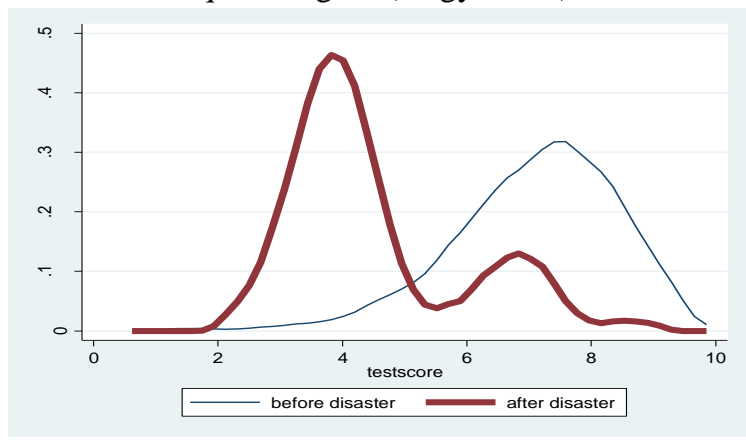

b. Non-earthquake region

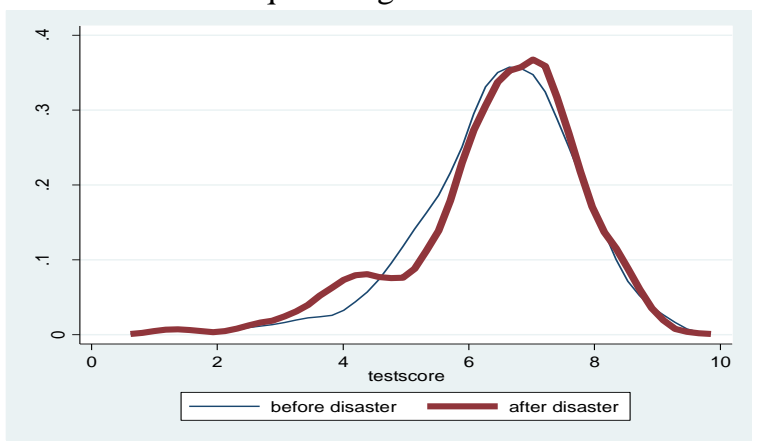

Figure 3: Child test score distribution in earthquake region and non-earthquake region

In addition, Figure 4 shows the common trend of child test scores for children in earthquake and non-earthquake regions and also for those who are directly affected, or unaffected, by the earthquake. Before the earthquake occurred in 2006, the average child test scores for both the earthquake region and the non-earthquake region were similar, but after the disaster there was a big gap between the child test scores in the earthquake region and the nonearthquake region. The same results are obtained for the affected and non-affected child test scores. The difference in the child test scores before the earthquake between those two groups was not that large, but after the earthquake a huge gap could be seen. It seemed that the child test scores in the earthquake region were badly affected by the disaster, especially for those who were directly affected. Moreover, as control variables, this paper added dummies for the parental educational background, there is a dummy for the primary school that is equal to 1 if the parent went to primary school, a dummy for the secondary school which is equal to 1 if the parent went to secondary school and a dummy for higher education which is also equal to 1 if the parent went to university. 
a. Child test scores in earthquake and non-earthquake region

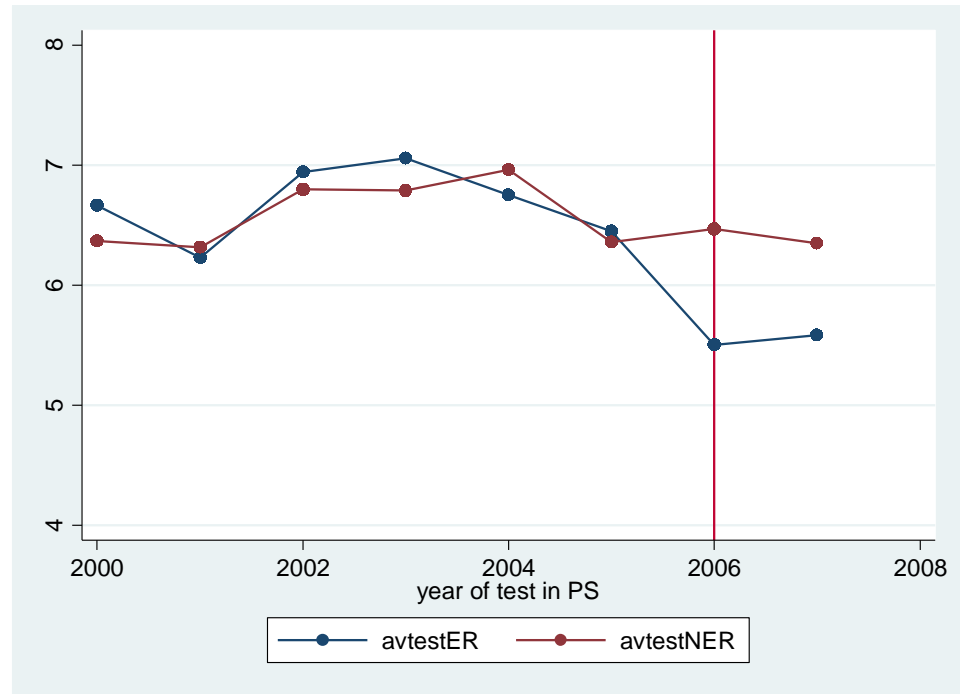

b. Child test scores of affected and non-affected directly

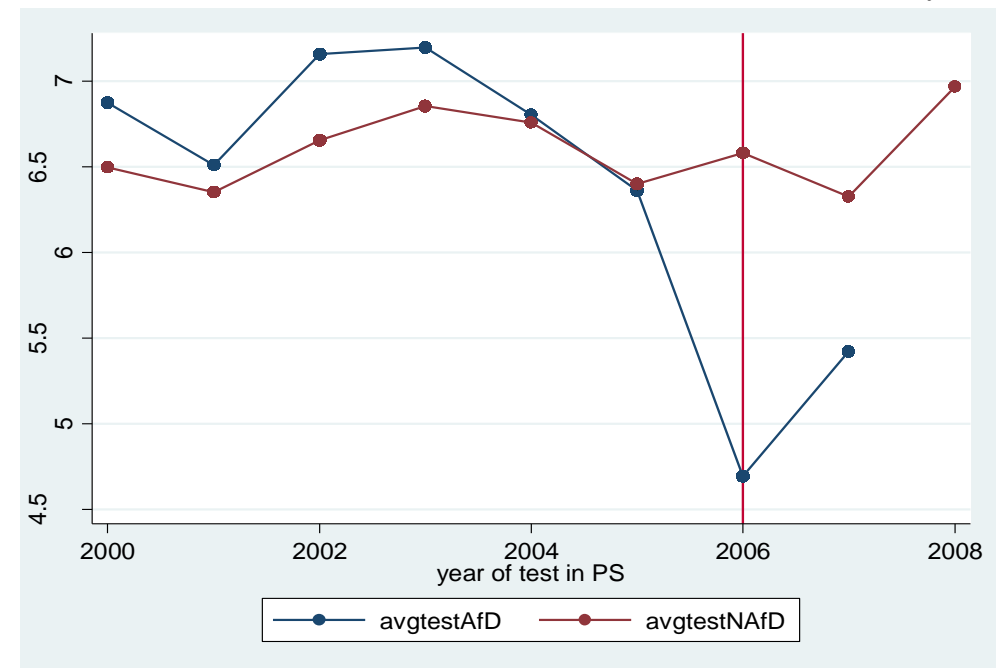

Source: Calculated from IFLS data wave 4 (2007)

Figure 4: Common Trend of Child Test Scores

\section{METHODOLOGY}

This paper used the Difference in Differences (DiD) method and a quantile regression. Difference in Differences (DiD) estimation is used when a certain group is exposed to the causal variable of interest, such as a change in government policy or a change in their environment due to a big shock, including disasters, while others are not. As an earthquake is a natural disaster, which is an exogenous condition that affects the economic environment, this paper uses this exogenous variation from natural disasters as a natural experiment to estimate the effects of earthquakes on child test scores in the affected area. The key assumption is on the potential outcome of the treatment group in the absence of an earthquake, and how to get this group when there is no data on what would have happened to individuals affected by an earthquake since the earthquake had not occurred. Therefore, DiD tries to find the solution to estimate this group by using other individuals that cannot be observed at the same time. Moreover, a quantile regression is used to examine the impact of an earthquake across the distribution of test scores.

On the other hand, Bertrand, Duflo and Mullainathan (2004) demonstrated that DiD 
estimates have a potential problem of serial correlation. They said that DiD has at least three factors that potentially cause serial correlation problems. First, DiD usually uses a time series data set. Second, dependent variables in DiD usually have a positive serial correlation. Third, as an intrinsic factor of a DiD model, the treatment variable can change very little. Those three issues can support each other so the true standard error of the parameter of the treatment variable can understate the standard deviation. To deal with a serious overestimation of $t$-values and significance levels in DiD estimations, this paper pays attention to the length of the time series data, the serial correlation of the dependent variables and also corrects the estimation. Bertrand, Duflo and Mullainathan (2004) offered 5 possible solutions to correct the serial correlation problem: a parametric method, a block bootstrap, ignoring the time series information, an empirical variance-covariance matrix and an arbitrary variance-covariance matrix. Here, this paper collapses the data into pre- and post-periods so it only has one period before and one period after the treatment (disaster) to cause any spurious inference in the DiD model. Thus, the ordinary least square (OLS) estimation provides a consistent standard error.

\section{Difference in Differences Method}

To illustrate the research design of the DiD method, this study defines $Y_{0 i}$ as a particular outcome of individual $i$ in the absence of an earthquake and $Y_{1 i}$ as a particular outcome of individual $i$ who experiences an earthquake in the region affected by the earthquake. Furthermore, $a_{i t}$ is equal to 1 if the individual reports that they were directly affected by the earthquake and $a_{i t}$ is equal to 0 if the individual was not directly affected. The definition of directly affected by the earthquake is if the earthquake was severe enough to cause death or major injuries to a household member, cause direct financial loss to the household, or cause the household's members to relocate. Hence, the DiD model can be written as:

$$
\begin{aligned}
& Y_{i t}=\alpha_{1} E R_{i t}+\alpha_{2}\left(E R_{i t} x a_{i t}\right)+u_{i t} \\
& Y_{i t}=\alpha_{1} E R_{i t}+\alpha_{2} A_{i t}+u_{i t}
\end{aligned}
$$

Note: $A_{i t}=E R_{i t} x a_{i t}$ and $u_{i t}=\gamma_{r}+v_{t}+\varepsilon_{i t}$

Where $\alpha_{l}$ is the effect of an earthquake on all of the individuals who live in the earthquake region at the time of the disaster. $\alpha_{2}$ is the effect of an earthquake for individuals who have been directly affected by the disaster. $\gamma_{r}$ is the regional effect, $v_{t}$ is the time effect, $\varepsilon_{i t}$ is a random error, $E R_{i t}=1$ is only for people in the earthquake region in the time after the disaster, $A_{i t}=1$ is only for people in the earthquake region in the time after the disaster who have been directly affected by the earthquake. Furthermore, $\alpha_{1}$ and $\alpha_{2}$ are the parameters of interest. Overall, $\alpha_{1}+\alpha_{2}$ are the effect of a disaster. When $E R_{i t}=0$ and $A_{i t}=0$ then $Y_{i t}=0$, and when $E R_{i t}=1$ and $A_{i t}=1$ then $Y_{i t}=\alpha_{1}+\alpha_{2}$.

Note that $E R_{i t}$ and $A_{i t}$ in Equation (1) above are interaction terms. $E R_{i t}$ indicates a dummy observation in an earthquake region after an earthquake and $A_{i t}$ as the interaction effect representing a dummy indicating the individuals in an earthquake region who have been affected by the earthquake. $A_{i r t}$ is the intensity effect of the earthquake, which is a subset of $E R_{i t}$, so $A_{i t}$ would be a marginal effect of being affected by the earthquake. This model can be expanded by including individual covariates $X_{i t}$ and can be written as:

$$
Y_{i t}=\alpha_{1} E R_{i t}+\alpha_{2} A_{i t}+\psi X_{i t}+u_{i t}
$$

Thus, there are two treatment groups: the first group is individuals in the earthquake region at the time of the earthquake and after the earthquake, and the second group is individuals in the earthquake region who report that they have been affected by the earthquake. Furthermore, the control group is comprised of individuals who are in a non-earthquake region and those in the earthquake region but who are not affected by the earthquake. The equation for the child test score can be written as:

$$
\begin{aligned}
\text { Test }_{\text {score }}= & \alpha_{0}+\alpha_{1} E R_{i}+\alpha_{2} A_{i}+ \\
& \psi X_{i}+\gamma_{r}+v_{t}+\varepsilon_{i}
\end{aligned}
$$


The dependent variable in this equation (test score $_{\mathrm{i}}$ ) is the child test score at age 11 for individual $i$. The average child test scores are used rather than the total child test scores, in order to make them comparable with different age groups of children, since there was a change in policy on the total number of subjects tested in 2002. Before 2002, 5 subjects were tested: (1) moral and civil education, (2) Bahasa Indonesia (Indonesian language), (3) maths, (4) science and (5) social studies. Starting in 2002, only 3 subjects were tested: (1) Bahasa Indonesia (Indonesian language), (2) maths, and (3) science. For test scores before 2002, we used test scores from the same subjects with the subjects that were tested after 2002. In addition, IFLS also reports whether the child did show their test score certificate or not. To avoid measurement error in the child test scores, this study only uses data from children who can prove their test score using their test score certificates.

The main explanatory variables are $E R_{i}$ and $A_{i}$, which capture the natural disaster variables. In addition, vector $X_{i}$ contains the other explanatory variables to capture individual and household characteristics, such as age, gender, the area where they live, and parental education background. The variables $\gamma_{r}$ and $v_{t}$ are used to control for regions and year fixed effects, respectively. The inclusion of the regional dummy variables reduces the potential bias from unmeasured regional shocks. Year dummy variables are useful to control for year specific characteristics and control for potential changes in the yearly test score.

\section{Quantile Regression}

A least squares regression can capture the change in the mean of the dependent variable, if there is a change in the independent variables. Yet sometimes, a single mean curve is not informative enough; conditional quantile functions provide a more complete view. Koenker and Bassett (1978) introduced quantile regression as a simple minimisation problem yielding the ordinary sample quantiles in the location model ${ }^{1}$. This method generalises naturally a new class of statistics from the linear model. Quantile regression is very useful for looking at the complete picture, showing information about the relationship between the outcome $Y_{i}$ child test scores and the covariates $\mathrm{X}_{\mathrm{i}}$, including the variables of interest $\left(\mathrm{ER}_{\mathrm{i}}\right.$ and $\mathrm{A}_{\mathrm{i}}$ ) at any of the different points in the conditional distribution of $\mathrm{Y}_{\mathrm{i}}$. Quantile regression is more robust for data with outliers, for instance, by looking at the median regression rather than the mean regression, since the median regression minimises the expected absolute error while the mean regression only minimises the expected squared. A quantile regression can be written as:

$$
\hat{Q}_{\tau}(Y \mid X)=X^{T} \hat{\beta}_{\tau}
$$

Where $\tau$ is the choice of quantile level $(0.05,0.1$, $0.15,0.2, \ldots, 0.9,0.95), X^{T}$ are the covariates, and $\hat{\beta}_{\tau}$ is the parameter of interest. For this study, the quantile regression model is:

$$
\begin{aligned}
& Q_{\tau}\left(\text { Test } \text { score }_{i}\right)=\alpha_{0}+\alpha_{1} E R_{i}+\alpha_{2} A_{i}+ \\
& \psi X_{i}+\gamma_{r}+v_{t}+\varepsilon_{i}
\end{aligned}
$$

\section{EMPIRICAL RESULTS}

This section discusses the results of the impact of earthquake on child test scores. There are several main estimation results: (1) the average impact of an earthquake, (2) the impact of an earthquake in the first and second years' aftermath. A DiD model is applied to estimate the outcome of interest. In addition, this paper applied a quantile regression to find out the impact of an earthquake on a different group of children's test scores. By using a QR, the extent to which the effect of an earthquake differs across the distribution of conditional test scores can be seen.

Moreover, the estimation results of this study are only the lower bound estimates of the impact of an earthquake on the child test scores. As Baez and Santos (2007) note, the reasons why the results are only a lower bound are that an earthquake is an aggregate shock, so it is

\footnotetext{
1 The detail explanation about the regression quantile is discussed by Koenker and Bassett (1978).
} 
possible that households who live in a nonearthquake region are indirectly affected by the earthquake. Furthermore, households who live in earthquake regions will normally receive financial assistance after an earthquake and those in a non-earthquake region will not. Although physically they were not hit by the earthquake, they probably needed financial aid due to the macro effects of the disaster.

\section{Difference in Differences Method}

Table 1 illustrates the Difference in Difference (DiD) estimation of the effect of an earthquake on the child test scores. The first column reports the average test scores before the earthquake, the second column reports the average test scores after the earthquake, and the third column is the difference between the after-earthquake child test scores and the before-earthquake child test scores. The rows present the average of the child test scores in earthquake regions, nonearthquake regions and the difference between those two regions. The after-earthquake child test scores in earthquake regions decreased by 1.14 points compared to the before-earthquake scores. Child test scores in non-earthquake regions decreased by only 0.03 points, and the difference between those two regions is -1.11 points as a DiD estimate of the impact of an earthquake on child test scores.
For the regression version of DiD estimators, there are six specifications based on different sets of control variables, which consist of sets of individual characteristics, interaction variables with the dummy variables of interest (ER and A) and also year dummies and regional dummies. The coefficient of ER represents the average impact of an earthquake on the child test scores for children who took the tests after an earthquake in the earthquake region, while the coefficient of A represents the additional impact of an earthquake on the child test scores for those being affected by an earthquake in the earthquake region. Table 2 shows the average impact of an earthquake on the child test scores. Both specifications confirm that earthquakes reduce the child test scores. Lower test scores are not only suffered by the children who are affected by the earthquake, but also children who are not affected by the earthquake in the earthquake region. This is not surprising, since most of the school buildings, transportation, telecommunication and infrastructure are destroyed and teachers are also affected by such disasters, so it is likely that all the schools are closed down at the time of and after the disaster. However, those who are affected by earthquakes have an even lower test score than those who are not affected.

Table 1. Difference in difference estimates of the effect of earthquake on child test scores

\begin{tabular}{lccc}
\hline & $\begin{array}{c}\text { Before earthquake } \\
(1)\end{array}$ & $\begin{array}{c}\text { After earthquake } \\
(2)\end{array}$ & $\begin{array}{c}\text { After-Before } \\
(3)\end{array}$ \\
\hline \multirow{2}{*}{ Earthquake region } & 6.51 & 5.37 & -1.14 \\
& $(0.02)$ & $(0.18)$ & $(0.14)$ \\
Non- earthquake & 6.49 & 6.46 & -0.03 \\
region & $(0.02)$ & $(0.05)$ & $(0.05)$ \\
ER-NER difference & 0.02 & -1.09 & -1.11 \\
& $(0.03)$ & $(0.19)$ & $(0.15)$ \\
\hline
\end{tabular}

Note: Standard errors in parentheses 
Table 2. Results of the Impact of an earthquake on Child Test Scores

\begin{tabular}{|c|c|c|}
\hline Dependent variable: test score & 1 & 2 \\
\hline \multirow[t]{2}{*}{ ER } & $-0.894 * * *$ & $-0.900 * * *$ \\
\hline & $(0.280)$ & $(0.276)$ \\
\hline \multirow[t]{2}{*}{ A } & $-0.994 * * *$ & $-1.054 * * *$ \\
\hline & $(0.270)$ & $(0.276)$ \\
\hline \multirow[t]{2}{*}{ Age } & & 0.000598 \\
\hline & & $(0.0159)$ \\
\hline \multirow[t]{2}{*}{ Urban } & & $0.264 * * *$ \\
\hline & & $(0.0278)$ \\
\hline \multirow[t]{2}{*}{ Male } & & $-0.0692 *$ \\
\hline & & $(0.0376)$ \\
\hline \multirow[t]{2}{*}{ Father_secondary school } & & 0.00673 \\
\hline & & $(0.0477)$ \\
\hline \multirow[t]{2}{*}{ Father_higher education } & & $0.327 * * *$ \\
\hline & & $(0.0676)$ \\
\hline \multirow[t]{2}{*}{ Mother_secondary school } & & $0.190 * * *$ \\
\hline & & $(0.0586)$ \\
\hline \multirow[t]{2}{*}{ Mother_higher education } & & $0.464 * * *$ \\
\hline & & $(0.137)$ \\
\hline Year dummies & yes & yes \\
\hline Region dummies & yes & yes \\
\hline Observation & 5,073 & 5,067 \\
\hline
\end{tabular}

Note: Standard errors in parentheses and asterisk denote statistical significance: $* * * 1 \%, * * 5 \%, * 10 \%$

In Model 2, by controlling for the individual characteristics, year dummies and regional dummies, the occurrence of an earthquake decreases the child test score by 0.900 for children in the earthquake region who took the test after the earthquake. For those who are affected by the earthquake there is a further reduction, by 1.054 , so being affected by an earthquake causes an even lower test score. In addition, children in urban areas have a better test score (by 0.26 on average) than children in rural areas. Moreover, boys also seem to suffer from lower test scores than girls - at $10 \%$ significance levels, by approximately 0.07 on average. Similarly this paper finds that a higher parental education background is associated with higher child test scores, especially for the maternal education background. The results in Table 2 also only used test scores from children who could show a test score certificate at the time of the IFLS survey. Those who could not show a certificate are dropped from this estimation, since their test scores' data are not complete. This selection issue may cause bias. Yet, this paper also provides an estimation for this, by using an imputation missing value for those who have incomplete test scores. The result is not very different to Table 4 , especially for the coefficients of variable interest, ER and A (see Appendix Table 1). 
Table 3. Results of the Impact of an earthquake on Child Test Scores by including covariates' interaction with A and ER dummies' variables

\begin{tabular}{|c|c|c|c|}
\hline & $\begin{array}{c}\text { Dependent variable: test } \\
\text { score } \\
(1)\end{array}$ & $\begin{array}{c}\text { (continuous) } \\
\text { Interaction with A } \\
\text { (2) }\end{array}$ & $\begin{array}{c}\text { (continuous) } \\
\text { Interaction with ER } \\
\text { (3) }\end{array}$ \\
\hline \multirow{2}{*}{ ER } & $-1.424 * * *$ & & \\
\hline & $(0.306)$ & & \\
\hline \multirow{3}{*}{ A } & $-0.712 * * *$ & & \\
\hline & $(0.221)$ & & \\
\hline & $\mathrm{A}=0 ; \mathrm{ER}=0$ & $\mathrm{~A}=1 ; \mathrm{ER}=1$ & $\mathrm{~A}=0 ; \mathrm{ER}=1$ \\
\hline \multirow{2}{*}{ Age } & 0.000715 & -0.0935 & $-0.599^{\star \star}$ \\
\hline & $(0.0159)$ & $(0.119)$ & $(0.217)$ \\
\hline \multirow{2}{*}{ Urban } & $0.263 * * *$ & $0.896^{* *}$ & $-0.650^{* *}$ \\
\hline & $(0.0264)$ & $(0.405)$ & $(0.282)$ \\
\hline \multirow{2}{*}{ Male } & $-0.0783^{* *}$ & $0.691^{\star *}$ & 0.183 \\
\hline & $(0.0355)$ & $(0.265)$ & $(0.234)$ \\
\hline \multirow{2}{*}{ Father_secondary school } & 0.00613 & 0.621 & $-0.725^{\star *}$ \\
\hline & $(0.0521)$ & $(1.233)$ & $(0.322)$ \\
\hline \multirow{2}{*}{ Father_higher education } & $0.337 * * *$ & $-0.742^{* *}$ & -0.245 \\
\hline & $(0.0702)$ & $(0.322)$ & $(0.364)$ \\
\hline \multirow{2}{*}{ Mother_secondary school } & $0.196 * * *$ & $-1.632^{\star \star \star}$ & $1.302^{* * *}$ \\
\hline & $(0.0547)$ & $(0.568)$ & $(0.283)$ \\
\hline \multirow{2}{*}{ Mother_higher education } & $0.450 * * *$ & $-1.262^{*}$ & $1.308^{* * *}$ \\
\hline & $(0.143)$ & $(0.635)$ & $(0.270)$ \\
\hline Year dummies & & Yes & \\
\hline Region dummies & & Yes & \\
\hline Observation & & 5,056 & \\
\hline
\end{tabular}

Note: Standard errors in parentheses and asterisk denote statistical significance: *** 1\%, ** 5\%, * $10 \%$

Table 3 shows the model with the interaction of explanatory variables with ER and A. Column 2 and Column 3 are the continuation of Column 1. Column 1 shows all the magnitude of the coefficient variables when $\mathrm{A}=0$ and $\mathrm{ER}=0$. Column 2 shows the magnitude of the coefficient from the interaction of all the explanatory variables with $\mathrm{A}$, or with condition $\mathrm{A}=1$ and $\mathrm{ER}=1$, while Column 3 is the magnitude coefficient of all the explanatory variables from the interaction with $\mathrm{ER}$ when $\mathrm{A}=$ 0 and $\mathrm{D}=1$. The idea of running this model specification is to investigate whether some people are more badly affected by disasters than others.

The results show that the interactions with $\mathrm{A}$ in Column 2 are positive and show significant effects for urban dwellers and males, but negative and significant for the fathers' and mothers' educational backgrounds. That means that, for those being affected by the earthquake, students in rural areas and females have lower test scores than students in urban areas or male students, relative to those people not directly affected by the earthquake. Furthermore, students who are directly affected by the earthquake with higher parental education backgrounds also have lower test scores relative to those not being directly affected by the earthquake. Column 3 shows that the interaction of ER with age, living in an urban environment and the father's education background has a negative coefficient, but a positive coefficient for the interaction with the maternal education background. This means that being in the earthquake region and living in an urban area 
has a more negative effect relative to not being in the earthquake region.

Table 4 compares the results of the impact of the earthquake on child test scores for children who took the test just after the disaster in 2006 and those tested one year after the disaster in 2007. The results confirm that children from the test year of 2006 in the earthquake region suffered a lower test score than those who took the test one year after the earthquake. Most probably, this is because the test in 2006 was only taken approximately one month after the earthquake occurred and the children's focus may not have been concentrated on taking the test at that time, due to the earthquake's influence.

Table 4. Results of the Impact of the earthquake on Child Test Score in the First and Second Years' Aftermath

\begin{tabular}{lcc}
\hline $\begin{array}{l}\text { Dependent variable: } \\
\text { test score }\end{array}$ & 1 & 2 \\
\hline ER2006 & $-1.662^{* * *}$ & $-1.646^{* * *}$ \\
& $(0.223)$ & $(0.226)$ \\
ER2007 & $-0.645^{* * *}$ & $-0.658^{* * *}$ \\
& $(0.0988)$ & $(0.102)$ \\
A2006 & $-1.248^{* * *}$ & $-1.318^{* * *}$ \\
& $(0)$ & $(0.0132)$ \\
A2007 & $-0.820^{* * *}$ & $-0.875^{* * *}$ \\
& $(0.155)$ & $(0.164)$ \\
Age & & 0.000359 \\
& & $(0.0159)$ \\
Urban & & $0.262^{* * *}$ \\
& & $(0.0276)$ \\
Male & & $-0.0725^{*}$ \\
& & $(0.0373)$ \\
Father_secondary school & & 0.0149 \\
& & $(0.0505)$ \\
Father_higher education & & $0.346^{* * *}$ \\
& & $(0.0722)$ \\
Mother_secondary school & & $0.184^{* * *}$ \\
& & $(0.0604)$ \\
Mother_higher education & & $0.442^{* * *}$ \\
Year dummies & & $(0.142)$ \\
Region dummies & yes & yes \\
Observation & yes & yes \\
Not:S_and & 5,062 & 5,056 \\
\hline
\end{tabular}

Note: Standard errors in parentheses and asterisk denote statistical significance: $* * * 1 \%, * * 5 \%$, $* 10 \%$
The children's 2006 test scores in the earthquake region decreased by 1.6 on average and decreased by an additional 1.2 for those who were affected by the earthquake. In 2007, the test scores in the earthquake region decreased by 0.6 on average, and for those who were affected by the earthquake, they suffered a negative marginal effect of approximately 0.7 .

\section{Quantile Regression}

Table 5 compares the estimation results across the quantiles and the OLS. There are two different specifications: (1) estimation without control variables and (2) estimation with control variables. The coefficients of ER and A vary across the quantiles. In Specification 1, most noticeably, the highly statistically significant coefficient of ER has a much greater impact in the low quartile $(\mathrm{q}=0.25)$ of child test scores, reducing it by approximately 1.75 . For the coefficient of A, the biggest impact on the child test scores occurs in the median regression $(\mathrm{q}=$ 0.50 ), decreasing it by approximately 2.39 .

In Specification 2, the quantile regression results are not very different from Specification 1. The lower group of children's test scores is badly affected by the earthquake, while the middle and upper groups have a similar impact and are less affected than the lower group. In addition, for those who are affected by the earthquake, the middle group of children's test scores are the worst affected by the earthquake, but the lower group is not significantly affected. The upper group is also affected but not as badly as the middle group. It might be that the academic ability of the middle group is only moderate, while the upper group is dominated by more able children, so the affected children in the middle group of test scores were badly influenced by this condition, more so than the children in the upper group of test scores, while the lower group of test score were also affected but not as much as the middle group or upper group. The quantile regression results differ considerably from the OLS coefficients. 
Table 5. Results of Impact of Natural Disaster on Child Test Score Across Quantiles

\begin{tabular}{|c|c|c|c|c|}
\hline (1) & OLS & QR_25 & QR_50 & QR_75 \\
\hline \multicolumn{5}{|c|}{ Estimation without control variables } \\
\hline \multirow[t]{2}{*}{ ER } & $-0.439 * *$ & $-1.750 * * *$ & $-0.547 * *$ & $-0.439 * *$ \\
\hline & $(0.213)$ & $(0.280)$ & $(0.224)$ & $(0.213)$ \\
\hline \multirow[t]{2}{*}{ A } & $-0.954 * * *$ & $-0.646^{*}$ & $-2.397 * * *$ & $-0.954 * * *$ \\
\hline & $(0.283)$ & $(0.372)$ & $(0.298)$ & $(0.283)$ \\
\hline \multicolumn{5}{|c|}{$(2)$} \\
\hline \multicolumn{5}{|c|}{ Estimation with control variables } \\
\hline \multirow[t]{2}{*}{ ER } & $-0.893 * * *$ & $-1.977 * * *$ & $-0.580 * * *$ & $-0.581 * * *$ \\
\hline & (0.199) & $(0.296)$ & $(0.221)$ & $(0.203)$ \\
\hline \multirow[t]{2}{*}{ A } & $-1.060 * * *$ & $-0.672^{*}$ & $-2.511 * * *$ & $-1.046 * * *$ \\
\hline & $(0.265)$ & $(0.394)$ & $(0.294)$ & $(0.270)$ \\
\hline \multirow[t]{2}{*}{ Age } & 0.00241 & 0.0174 & -0.00416 & 0.00405 \\
\hline & $(0.00962)$ & $(0.0143)$ & $(0.0106)$ & $(0.00981)$ \\
\hline \multirow[t]{2}{*}{ Urban } & $0.273 * * *$ & $0.218 * * *$ & $0.225 * * *$ & $0.290 * * *$ \\
\hline & $(0.0386)$ & $(0.0573)$ & $(0.0428)$ & $(0.0394)$ \\
\hline \multirow[t]{2}{*}{ Male } & $-0.0753^{* *}$ & -0.0228 & $-0.121 * * *$ & $-0.178 * * *$ \\
\hline & $(0.0353)$ & $(0.0523)$ & $(0.0390)$ & $(0.0360)$ \\
\hline \multirow[t]{2}{*}{ Father_secondary school } & -0.0340 & -0.0553 & 0.00306 & 0.0236 \\
\hline & $(0.0505)$ & $(0.0750)$ & $(0.0559)$ & $(0.0515)$ \\
\hline \multirow[t]{2}{*}{ Father_higher education } & $0.291 * * *$ & 0.219 & $0.378 * * *$ & $0.357^{* * *}$ \\
\hline & $(0.0920)$ & $(0.136)$ & $(0.102)$ & $(0.0937)$ \\
\hline \multirow[t]{2}{*}{ Mother_secondary school } & $0.165 * * *$ & $0.222 * * *$ & $0.122 * *$ & $0.193^{* * *}$ \\
\hline & $(0.0512)$ & $(0.0759)$ & $(0.0566)$ & $(0.0521)$ \\
\hline \multirow[t]{2}{*}{ Mother_higher education } & $0.444^{* * *}$ & $0.402 * *$ & $0.545^{* * *}$ & $0.495 * * *$ \\
\hline & (0.109) & $(0.162)$ & $(0.121)$ & $(0.111)$ \\
\hline
\end{tabular}

\section{FURTHER ROBUSTNESS CHECKS}

This paper conducts several robustness checks to ensure that the results are robust. First, this study re-estimated the models, excluding the rural child test scores. This was done since most of the income of parents in rural areas come from the agricultural sectors. So a crop failure is associated with decreasing test scores. The results are presented in Table 6. All the results confirm that the coefficient of the variables of interest is close to the OLS results obtained without excluding the rural area data. As it can be seen from Column 1, using the OLS estimation, all the variables of interest (A and ER) are highly significant at $1 \%$. Secondly, according to Bertrand, Duflo and Mullainathan
(2004) there is a potential serial correlation problem in the DiD model. This study examines this by collapsing the time into two periods before and after the disaster - then re-estimating.

Another check for serial correlation is by aggregating the time dimension of the child test scores. This study aggregated the year when the children were tested into two periods: before the earthquake and after the earthquake. This study re-estimated across these two periods and these results are reported in Table 7. The results show that the effect of the disaster for both variables of interest is statistically significant at the $1 \%$ level, and the coefficient of those variables is similar. This suggests that our estimates are not a result of any serial correlation. 
Table 6. Results of the Impact of the earthquake on Child Test Score, Excluding Rural Area

\begin{tabular}{lc}
\hline Dependent variable: test score & 1 \\
ER & OLS \\
\hline A & $\left(0.031^{* * *}\right.$ \\
& $-0.829 * *$ \\
Age & $(0.352)$ \\
& 0.007 \\
Male & $(0.014)$ \\
& -0.080 \\
Father_secondary school & $(0.050)$ \\
& -0.003 \\
Father_higher education & $(0.082)$ \\
& $0.306 * *$ \\
Mother_secondary school & $(0.126)$ \\
& $0.128^{* * *}$ \\
Mother_higher education & $(0.074)$ \\
Year dummies & $0.371 * * *$ \\
Region dummies & $(0.135)$ \\
\hline Observation & yes \\
\end{tabular}

Note: Standard errors in parentheses and asterisk denote statistical significance: $* * * 1 \%, * * 5 \%$, $* 10 \%$;
Table 7. The Impact of Earthquake on Child Test Scores by Aggregating Data

\begin{tabular}{lcc}
\hline \multicolumn{1}{c}{$\begin{array}{c}\text { Dependent variable: } \\
\text { test score }\end{array}$} & 1 & 2 \\
\hline ER & $-0.901^{* * *}$ & $-0.967^{* * *}$ \\
& $(0.199)$ & $(0.199)$ \\
A & $-0.959^{* * *}$ & $-0.943^{* * *}$ \\
& $(0.276)$ & $(0.278)$ \\
Age & -0.001 & $-0.023^{* * *}$ \\
& $(0.010)$ & $(0.006)$ \\
Urban & $0.265^{* * *}$ & $0.257^{* * *}$ \\
& $(0.039)$ & $(0.039)$ \\
Male & $-0.069^{*}$ & $-0.061^{*}$ \\
& $(0.035)$ & $(0.035)$ \\
Father_secondary school & 0.002 & 0.004 \\
& $(0.057)$ & $(0.057)$ \\
Father_higher education & $0.324^{* * *}$ & $0.327^{* * *}$ \\
& $(0.096)$ & $(0.097)$ \\
Mother_secondary school & $0.191^{* * *}$ & $0.185^{* * *}$ \\
& $(0.054)$ & $(0.054)$ \\
Mother_higher education & $0.460^{* * *}$ & $0.468^{* * *}$ \\
& $(0.111)$ & $(0.111)$ \\
Year dummies & yes & yes \\
Region dummies & yes & yes \\
Observation & 5,067 & 5,067 \\
\hline Not Standard &
\end{tabular}

Note: Standard errors in parentheses and asterisk denote statistical significance: $* * * 1 \%$, ** 5\%, $* 10 \%$; Column 1 is the original OLS regression; column 2 is for aggregating data.

earthquake on child test scores. Earthquakes affect all of the children in an earthquake region, both those who are affected and those who say they are unaffected by the earthquake, by reducing their test scores. Those who are affected by an earthquake have a much lower test score than those who are not affected. Moreover, children who took the test just after the earthquake had a lower test score than children who took the test more than a year after the earthquake. Being in a region that is hit by earthquakes has the biggest impact on the child test scores in the lowest quantile of test scores. Moreover, the largest additional impact of an earthquake, on those who have been affected by

The main findings are as follows. The first major finding is related to the effects of the 
earthquakes, is on children at the median of the test score's distribution.

In terms of gender, there is no difference in the impact of the earthquake on girls' child test scores and boys' scores, for those who live in the earthquake region and were directly affected by the earthquake. In terms of the area, the impacts of the earthquake on the child test scores show that children in rural areas suffer more than children in urban areas. In the long term, related with child education, the government should give more consideration and priority to rural areas, rather than urban areas, and quickly rebuild the school buildings and facilities for children. By providing enough assistance for the victims, especially children, the human capital outcomes of children are not badly affected by the shock that is caused by disasters, as the future lives of children are definitely influenced by the outcomes from their experiences when they were young.

\section{REFERENCES}

Asgary, A., \& Willis, K. G. (1997). Household behaviour in response to earthquake risk: an assessment of alternative theories. Disaster, 21(4), 354-365.

Athey, S., \& Imbens, G. (March 2006). Identification and Inference in Nonlinear Difference in Differences Models. Econometrics, 74(2),431-497.

Baez, J. E., \& Santos, I. V. (2007). Children‘s Vulnerability to Weather Shocks: A Natural Disaster as a Natural Experiment. Working paper.

Baez, J., Fluente, A. D. L., \& Santos, I. (2010). Do natural disasters affect human capital? An assessment based on existing empirical evidence. The Institute for the Study of Labor (IZA), IZA DP No. 5164,1-60.

Becker, G. S. (1964). Human Capital A theoritical Analysis with Special Reference to Education. New York: The National Bureau of Economic Research.

Beegle, K., Dehejia, R., \& Gatti, R. (2003). Child labour, crop shocks, and credit constraints. National Bureau of Economic Research, NBER Working paper no.10088.
Bertrand, M., Duflo, E., \& Mullainathan, S. (2004). How much should we trust differences in differences estimates? Quarterly Journal of Economics, 119(1), 249-275.

Blundell, R., Dearden, L., \& Sianesi, B. (2005). Evaluating the effect of education on earnings: models, methods and results from the national child development survey. Royal Statistics Society, 168(3), 473-513.

Bustelo, M., Arends-Kuenning, M., \& Lucchetti, L. (February 2012). Persistent impact of natural disasters on child nutrition and schooling: evidence from the 1999 Colombian earthquake. The Institute for the Study of Labor (IZA) discussion paper no. 6354.

Cameron, L. A., \& Worswick, C. (2001). Education Expenditure Responses to Crop Loss in Indonesia. Economic Development and Cultural Change, 49(2), 351363.

Canay, I. A. (2011). A Simple Approach to Quantile Regression for Panel Data. The Econometrics Journal, 14, 368-386.

Card, D. (2001). Estimating the Return to Schooling:Progress on Some Persistent Econometric Problem. Econometrica, 69(5), 1127-1160.

Carter, M.R., Little, P.D., Mogues, T \& Negatu, W. (2007). Poverty Traps and Natural Dissaster in Ethiopia and Honduras. World Development, 35(5), 835856.

Currie, J., \& Thomas, D. (2001). Early test scores, school quality, and social economic status: longrun effects on wage and employment outcome. Worker Wellbeing in a Changing Labor Market, 20, 103-132.

Dammert, A. C. (2008). Child labor and schooling response to changes in coca production in rural Peru. Journal of Development Economics, 86, 164-180.

Dercon, S. (2004). Growth and shocks: evidence from rural Ethiopia. Journal of Development Economics, 74, 309329.

Frankenberg, E., \& Karoly, L. (November 1995). The 1993 Indonesian Family Life Survey: Overview and Field Report. RAND Labor and Population, DRU-1195/1NICH/AID.

Frankenberg, E., \& Thomas, D. (March 2000). The Indonesia Family Life Survey (IFLS): 
Study Design and Results from Waves 1 and 2. RAND Labor and Population, DRU2238/1-NIA/NICHD.

Giles, J., \& Satriawan, E. (2010). Protecting Child Nutritional Status in the Aftermath of a Financial Crisis. The World Bank, Policy research working paper no. 5471.

Gitter, S. R., \& Barham, B. (2007). Credit, Natural Disasters, Coffee, and Educational Attainment in Rural Honduras. World Development, 35(3), 498-511.

Glewwe, P., Jacoby, H., \& King, E. (1999). Early Childhood Nutrition and Academic Achievement: A longitudinal analysis. International Food Policy Research Institute, FCND DP No.68.

Greene, W. H. (2012). Econometric Analysis. Edinburgh Gate: Pearson Education Limited.

Jacoby, H. G., \& Skoufias, E. (1997). Risk, financial markets, and human capital in a developing country. Review of Economic Studies, 64, 311-335.

Jehle, G. A., \& Reny, P. (2001). Advanced Microeconomic Theory. London: The Addison-Wesley.

Jensen, R. (2000). Agricultural volatility and investment in children. American Economic Review, 90(2), 399-404.

Kahn, M. E. (2005). The death toll from natural disasters: the role of income, geography, and institutions. The Review of Economic and Statistics, 87(2), 271-284.

Kankwamba, H., Mangisoni, J., Simtowe, F., Mausch, K., \& Siambi, M. (2012). Improved legume seed demand systems in central Malawi: what do farmers' seed expenditures say abaout their preferences? International Association of Agricultural Economist, 1-26.

Kennan, J. (1985). The Duration of Contract Strikes in US Manufacturing. Journal of Econometrics, 28, 528.

Kochar, A. (1999). Smoothing consumption by smoothing income: hours-of-work responses to idiosyncratic agricurtural shocks in rural India. The Review of Economics and Statistics, 81(1), 50-61.

Koenker, R., \& Bassett, G. (1978). Regression Quantiles. Econometrica, 46(1), 33-50.
Lalonde, R. J. (1986). Evaluating the Econometric Evaluation of Training Programs with Experimental Data. American Economic Review, 76(4), 604-620.

Lasky, R. E., Klein, R. E., Yarbrough, C., Engle, P. L., Lechtig, A., \& Martorell, R. (1981). The relationship between physical growth and infant behavioural development in rural Guatemala. Child Development, 52(1), 219226.

Lee, M. J., \& Kang, C. (2006). Identification for difference in differences with cross-section and panel data. Economic Letters, 92, 270276.

Maluccio, J. A., Haddinott, J., Behrman, J., Martorell, R., \& Quisumbing, A. (2006). The Impact of Nutrition during Early CHildhood on Education among Guatemalan Adults. Population Studies Center University of Pennsylvania, Working paper.

Marshall, A. (1961). Principles of Economics (9th Ed.). London: Macmillan.

Mincer, J. (1958). Investment in human capital and personal income distribution. The Journal of Political Economy, 66, 281-302.

Morduch, J. (1995). Income smoothing and consumption smoothing. The Journal of Economic Perspectives, 9(3), 103-114.

Neumayer, E., \& Plumper, T. (2007). The gendered nature of natural disasters: the impact of catastrophic events on the gender gap in life expectancy, 1981-2002. Annals of the Association of American Geographers, 97(3), 551-566.

Nichols, A. (2007). Causal Inference with Observational Data. The Stata Journal, 7(4), 507-541.

Ninno, C. D., \& Dorosh, P. (2003). Public Policy, Markets and Household Coping in Bangladesh: Avoiding a Food Security Crisis Following the 1998 Floods. World Development, 31(7), 1221-1238.

Ninno, C. D., \& Lundberg, M. (2005). Treading water the long term impact of the 1998 flood on nutrition in Bangladesh. Economics and Human Biology, 3, 67-96.

Ninno, C. d., \& Lundberg, M. (2005). Treading water the long-term impact of the 1998 flood on nutrition in Bangladesh. Economics and Human Biology, 3, 67-96. 
Ninno, C. D., Dorosh, P. A., Smith, L. C., \& Roy, D. K. (1998). The 1998 Floods in Bangladesh. International Food Policy Research Institute, 1-114.

Palm, R. (1998). Urban earthquake hazards. Applied Geography, 18(1), 35-46.

Paxson, C. H. (1992). Using weather variability to estimate the response of savings to transitory income in Thailand. The American Economic Review, 82(1), 15-33.

Puhani, P. A. (April 2008). The Treatment Effect, the Cross Difference, and the Interaction Term in Nonlinear Difference in Differences Models. The Institute for the Study of Labor (IZA), IZA DP No.3478.

RAND. (2010, May 24). RAND Labour and Population Program. Retrieved from Indonesia Family Life Survey: http:// www.rand.org/labor/FLS/IFLS/

Riccio, James, Dechaussay, N., Greenberg, D., Miller, C., Rucks, Z., \& Verma, N. (2010). Toward Reduced Poverty Across Generations: Early Findings from New York City's Conditional Cash Transfer Program. New York: MDRC.

Rose, A., \& Lim, D. (2002). Business interuption losses from natural hazards: conceptual and methodological issues in the case of Northridge earthquake. Environment Hazards, 4, 1-14.

Skoufias, E. (2003). Economic crises and natural disasters: coping strategies and policy implications. World Development, 31(7), 1087-1102.

Smith, A. (1969). An inquiry into the nature and causes of the wealth of nations. In Arthur Hugh Jenkins (Eds.). Port Washington, N.Y: Kennikat Press (Original work published 1776).

Smith, S. K., \& McCarty, C. (1996). Demographic effects of natural disasters: a case study of Hurricane Andrew. Demography, 33(2), 265-275.

Sparrow, R. (2007). Protecting Education for the Poor in Times of Crises: An Evaluation of a Scholarship Programme in Indonesia. Oxford Bulletin of Economics and Statistics, 69 (1), 99-122.

Sunderlin, W. D., Angelsen, A., Resosudarmo, D. P., Dermawan, A., \& Rianto, E. (2001). Economic crisis, smal farmer well-being, and forest cover change in Indonesia. World Development, 29(5), 767-782.

The World Bank. (2010, November 18). Data. Retrieved from Indicators: http://data. worldbank.org

Thomas, D., Witoelar, F., Frankenberg, E., Sikoki, B., Strauss, J., Sumantri, C., \& Suriastini, W. (2010). Cutting the costs of attrition: Results from the Indonesia Family Life Survey. RAND.

Toya, H., \& Skidmore, M. (2007). Economic development and the impacts of natural disasters. Economics Letters, 94, 20-25.

Trostel, P., Walker, I., \& Woolley, P. (2002). Estimates of the economic return to schooling for 28 countries. Labour Economics, 9, 1-16.

Ureta, M. (2005). Hurricane Mitch, Family Budget and Schooling in Nicaragua. Working Paper, Departement of Economics Texas A\&M University.

Webb, G. R., Tierney, K. J., \& Dahlhamer, J. M. (2002). Predicting long term business recovery from disaster: a comparison of the Loma Prieta earthquake and Hurricane Andrew. Environmental Hazards, 4, 45-58.

Wong, P. Y., \& Brown, P. (2011). Natural Disasters and Vulnerability: Evidence from the 1997 Forest Fires in Indonesia. The B.E. Journal of Economic Analysis \& Policy, 11(1), 66. 


\section{Appendix}

Table 1 is the DiD estimation for the impact of disasters on child test scores using child test scores with imputation for the missing values.

Table 1. Results on the Impact of Disasters on child test scores

\begin{tabular}{|c|c|c|}
\hline VARIABLES & $\begin{array}{c}(1) \\
\text { Test score }\end{array}$ & $\begin{array}{c}(2) \\
\text { Test score }\end{array}$ \\
\hline ER & $\begin{array}{c}-1.061 * * * \\
(0.335)\end{array}$ & $\begin{array}{c}-1.079 * * * \\
(0.329)\end{array}$ \\
\hline A & $\begin{array}{c}-0.923^{* * *} \\
(0.197)\end{array}$ & $\begin{array}{c}-0.986 * * * \\
(0.201)\end{array}$ \\
\hline age & & $\begin{array}{c}0.000819 \\
(0.0155)\end{array}$ \\
\hline urban & & $\begin{array}{c}0.306^{* * * *} \\
(0.0241)\end{array}$ \\
\hline male & & $\begin{array}{l}-0.0701 * \\
(0.0375)\end{array}$ \\
\hline Father secondary & & $\begin{array}{l}-0.00268 \\
(0.0489)\end{array}$ \\
\hline Father higher education & & $\begin{array}{c}0.314 * * * \\
(0.0601)\end{array}$ \\
\hline Mother secondary & & $\begin{array}{c}0.170 * * * \\
(0.0489)\end{array}$ \\
\hline Mother higher education & & $\begin{array}{c}0.447 * * * \\
(0.123)\end{array}$ \\
\hline Constant & $\begin{array}{c}5.883 * * * \\
(0.150)\end{array}$ & $\begin{array}{c}5.395 * * * \\
(0.421)\end{array}$ \\
\hline Year dummies & yes & Yes \\
\hline Region dummies & yes & Yes \\
\hline Observations & 9,867 & 9,858 \\
\hline R-squared & 0.072 & 0.103 \\
\hline
\end{tabular}

Robust standard errors in parentheses

$* * * \mathrm{p}<0.01, * * \mathrm{p}<0.05, * \mathrm{p}<0.1$

Notice: The Journal of Indonesian Economy and Business and its Board of Editors are not responsible for any errors or flaws found in this article. The authors take full responsibility for their work. 